\title{
NIKAH SIRI DI WARUREJO DALAM PERSPEKTIF SEJARAH
}

\author{
Thriwaty Arsal1, Ekawati S.Wahyuni², Nurmala K.Pandjaitan², \\ Aida Vitayala S. Hubeis ${ }^{2}$ \\ 1) Jurusan Sosiologi dan Antropologi, Fakultas Ilmu Sosial, Universitas Negeri Semarang, \\ email: thriwatyarsal@yahoo.com \\ 2) Program Studi Sosiologi Pedesaan, Sekolah Pascasarjana, Institut Pertanian Bogor
}

\begin{abstract}
Siri Marriage (unofficial marriage) is not a new phenomenon in Indonesia with its all negative impacts. However, in Warurejo village, siri marriage is accepted widely by society particularl actors and siri marriage network. Siri marriage is a legal activity based on Islam if corresponding with legal requirements of marriag. Location of the research is conducted in Warurejo village, East Java through qualitative, quantitative and semantics approaches. The result of research shows that siri marriage in Warurejo has been long standing and hereditary since Madura ethnic migrates to Warurejo. Siri marriage initially occurs among migrants, gradually changing and leading to commercialization. Warurejo people cannot predict the exact time when the commercialization of siri marriage applied in Warurejo village, but surely after commercialization occurs, there is a workplace for brokers and clerics. Economy needs sometimes cause the actors ignoring the negative impacts as a result of siri marriage, such as domestic violence, child custo$d y$, inheritance, etc. If there is a divorce, it is only delivered by brokers or short messages through mobile phone.
\end{abstract}

Keyword: siri marriage, siri marriage network, value system dan religious norms

\begin{abstract}
ABSTRAK
Nikah siri bukanlah fenomena baru di Indonesia dengan segala dampak negatifnya. Namun, di Desa Warurejo nikah siri diterima secara luas oleh masyarakat, terutama aktor dan jaringan nikah siri. Nikah siri merupakan tindakan yang sah menurut agama Islam sepanjang sesuai syarat sahnya pernikahan. Lokasi penelitian di lakukan di desa Warurejo Jawa Timur.dengan menggunakan pendekatan kualitatif, kuantitatif dan semantik. Hasil penelitian menunjukkan bahwa nikah siri di Warurejo sudah berlangsung lama dan turun temurun. Sejak etnis Madura melakukan migrasi ke Warurejo. Nikah siri yang awalnya terjadi hanya sesama migran, lambat laun mengalami perubahan dan mengarah ke komersilisasi. Masyarakat Warurejo tidak bisa memperkirakan sejak kapan komersilisasi nikah siri mulai berlaku di Desa Warurejo, namun yang pasti sejak adanya komersilisasi maka sejak itu pula mulai memunculkan lahan pekerjaan baru bagi para broker dan kyai/modin. Kebutuhan terhadap ekonomi menyebabkan pelaku terkadang mengabaikan fungsi negatif yang diakibatkan oleh nikah siri, misalnya adanya kekerasan dalam rumah tangga, hak asuh anak, waris, dan lain-lain. Jika terjadi perceraian, maka perceraian itu hanya disampaikan melalui broker atau pesan pendek melalui telepon seluler.
\end{abstract}

Keyword: Nikah siri, jaringan nikah siri, sistem nilai dan norma agama

\section{PENDAHULUAN}

Nikah siri bukanlah fenomena baru di Indonesia, namun sudah ada sejak puluhan tahun silam. Sebelum pencatatan pernikahan, nikah siri sah menurut agama dan masyarakat. Karena modal sosial ekonomi dan strategi nafkah beru- bah, maka hak sipil juga berubah dengan berbagai dampak negatif yang ditimbulkan oleh nikah siri.

Berdasarkan hukum positif dan Undang-Undang Perkawinan 1974 dianggap melanggar norma walaupun dalam agama Islam nikah siri merupakan tindakan yang sah sepanjang sesuai 
dengan syarat sahnya pernikahan. Dengan kondisi demikian, di Warurejo yang merupakan salah satu desa di Jawa Timur ada perkawinan yang dianggap illegal namun secara formal diterima luas oleh masyarakat baik pasangan nikah siri maupun para kyai, khususnya yang menikahkan pasangan nikah siri. Masyarakat boleh melakukan nikah siri baik dengan warga setempat maupun dengan warga dari luar. Di desa Warurejo, nampaknya ada jaringan nikah siri yang melibatkan warga desa, pihak desa dan pihak keamanan untuk melindungi pihak-pihak yang terlibat dalam jaringan nikah siri sehingga siapapun yang ingin nikah siri dapat dengan mudah melakukan nikah siri di desa tersebut.

Nikah siri di desa Warurejo, menyerupai dengan nikah siri secara umum yang dikenal oleh masyarakat, artinya pasangan yang menikah siri tetap di hadiri oleh saksi-saksi, ada mahar, ada ijab kabul dan ada wali sebagai rukun nikah. Yang membuat nikah siri di Warurejo berbeda dan spesifik, karena memiliki tipologi tertentu. Individu yang telah berpisah atau ditinggal oleh pasangan nikah sirinya boleh menikah secara siri lagi dengan laki-laki lain, baik melalui broker maupun melalui perjodohan antarkerabat yang dilakukan oleh orang tua aktor.

Walaupun faktor ekonomi yang memotivasi perempuan untuk menikah siri berkali-kali namun sistem nilai, norma dan agama ikut berpengaruh terhadap keputusan perempuan dalam menikah siri. Ketika seorang perempuan yang berstatus janda, baik ditinggal mati ataupun perceraian, masyarakat akan "mengucilkan" dan memberikan penilaian yang negatif terhadap perempuan janda tersebut. Hal ini merupakan persoalan tersendiri bagi seorang perempuan khususnya bagi mereka yang memiliki anak dari hasil nikah siri.
Ketika ditinggal begitu saja oleh pasangannya tanpa jaminan ekonomi. Beberapa informan perempuan pelaku akan "cuti" dari nikah siri, namun demi untuk memenuhi tuntutan sosial budaya maka perempuan menikah siri lagi dengan harapan mendapatkan pasangan yang mampu menjamin dan meningkatkan kehidupan ekonomi mereka. Walaupun pada kenyataannya tidak semua pernikahan siri mampu meningkatkan kehidupan ekonomi sebagaimana yang diharapkan, namun nikah siri tetap eksis dan langgeng pada komunitas tersebut.

Eksis dan langgengnya nikah siri di Warurejo karena tokoh masyarakat setempat memberi legitimasi dan mendukung tindakan subyektif aktor untuk melakukan nikah siri sehingga nikah siri tetap langgeng dan eksis. Nikah siri di Warurejo tidak hanya terjadi pada masyarakat setempat tetapi masyarakat yang datang dari luar desa boleh dan bisa mampir untuk melakukan nikah siri. Nikah siri di Warurejo tidak hanya mendapat legitimasi dari lembaga formal dan informal dalam struktur masyarakat. Selain itu, jaringan nikah siri memiliki peranan yang besar dalam melanggengkan nikah siri. Karena secara ekonomi, kepentingan livelihood sangat berkorelasi dengan di langgengkannya nikah siri, pihak-pihak yang terlibat (jaringan nikah siri) ikut menikmati fungsi positif dari nikah siri.

Analisis perspektif struktural fungsional menjelaskan, jika suatu fenomena sosial eksis berarti fenomena sosial tersebut mempunyai fungsi positif (fungsional) dalam masyarakat. Dengan kata lain, fenomena sosial itu eksis karena ia berfungsi bagi sistem sosial budaya di mana ia berada (Merton, 1949; Merton, 1968). Nikah siri tetap eksis karena dalam ruang sosial memiliki fungsi dalam bentuk integrasi sosial legal-unlegitimate, sehingga 
Nikah Siri di Warurejo ... - Thriwaty Arsal, dkk.

ada pihak-pihak yang ingin melanggengkan nikah siri.

Selain itu, ada kebutuhankebutuhan pokok yang tidak terpenuhi dalam lembaga formal. Parsons dengan sistem nilai, norma, roles dan status mengungkapkan bahwa perilaku nikah siri yang dilakukan individu ditentukan oleh struktur untuk mempertahankan sistem di mana struktur itu menentukan perilaku individu. Motif pernikahan yang berbeda ini oleh Weber dimaknai sebagai tindakan rasional dan irrasional artinya pernikahan siri yang terjadi karena ada pengaruh tradisi dan budaya. Pernikahan selanjutnya lebih didasarkan pada tindakan rasional yang penuh arti subyektif dari aktor pelaku nikah siri.

Tindakan individu untuk menikah berkali-kali merupakan tindakan rasional Weber yaitu untuk mencapai tujuan atas sasaran dengan sarana-sarana yang paling tepat yaitu menikah siri untuk meningkatkan kehidupan ekonomi. Selain untuk meningkatkan ekonomi keluarga, tindakan perempuan untuk menikah siri berkali karena adanya pengaruh dari nilai-nilai budaya masyarakat yang lebih menghormati perempuan yang sudah menikah walaupun siri daripada perempuan janda. Namun, di sisi lain, ada pihak-pihak yang menganggap bahwa nikah siri itu tidak positif (disfunction). Dalam ruang hukum nikah siri eksis bukan karena fungsional tetapi ada sumber legitimasi lain yang mengukuhkan nikah siri.

Pernikahan siri bukan hanya bentuk pernikahan yang diterima dari segi agama, namun sebenarnya bukan sesuatu yang ideal karena dalam persepsi umum nikah siri tetap dianggap sebagai sesuatu yang negatif dan merupakan fenomena sosial yang diharapkan sesuai dan tidak bertentangan dengan budaya, norma-norma dan etika sosial yang berlaku pada masyarakat. Jika dipandang negatif oleh masyarakat mengapa di desa Warurejo nikah siri begitu meluas di masyarakat bahkan orang luar boleh menikah siri di desa tersebut.

Dari penjelasan di atas maka penelitian ini sesungguhnya bertujuan untuk mengeksplorasi pertanyaanpertanyaan berikut; Bagaimana perkembangan nikah siri di Warurejo? Bagaimana sejarah munculnya mafia nikah siri?

\section{METODE PENELITIAN}

Penelitian dilaksanakan di Desa Warurejo, salah satu desa di Jawa Timur. Desa Warurejo dikenal sebagai desa nikah siri di Jawa Timur sebab seratus persen penduduknya boleh dan bisa nikah siri, termasuk pasangan yang berasal dari luar di desa Warurejo ataupun laki-laki yang akan menikah siri dengan perempuan desa tersebut. Informan utama dalam penelitian ini adalah aktor/elite (kelembagaan dan kepemimpinan), aktor nikah siri (lakilaki dan perempuan pelaku nikah siri), broker nikah siri, keluarga perempuan pelaku nikah siri dan pihak-pihak yang terkait dengan fokus dan permasalahan penelitian. Informan penelitian dipilih dengan teknik snowball sampling, Sugiyono (2000).

Penelitian ini menggunakan paradigma pascapositivisme dengan pendekatan kualitatif dan kuantitatif yang ditunjang dengan sejarah lisan (oral history). Unit analisis dalam penelitian ini adalah komunitas dan individu (lakilaki dan perempuan sebagai aktor nikah siri) dan Teknik analisis data yang digunakan dalam penelitian ini menggunakan analisis kualitatif. Kemudian, data yang terkumpul dan derajat kebenaran dalam penelitian kualitatif tidak dapat ditetapkan secara pasti (masalah validitas internal), namun peneliti akan berusaha meraih 
tingkat kebenaran dengan menguji keabsahan data melalui cara-cara, melakukan trianggulasi metode dan trianggulasi sumber.

\section{HASIL DAN PEMBAHASAN}

\section{Sejarah Nikah Siri di Desa Warurejo}

Tidak ada yang bisa memberikan informasi dan keterangan pasti sejak kapan nikah siri mulai berkembang di Warurejo. Menurut informan Rudi (67 tahun), tokoh masyarakat dan merupakan penduduk asli masyarakat Warurejo. Pernikahan siri di Warurejo sudah ada sejak zaman penjajahan Belanda yang dilakukan oleh pelarian (migrasi) etnis Madura. Hal tersebut sudah berlangsung lama bahkan sudah turuntemurun. Hal ini diperkuat oleh pernyataan salah seorang informan (kiai) yang biasa menikahkan siri bagi pasangan yang akan menikah siri bahwa sejak dahulu mulai dari kakek buyutnya hingga generasi ke tujuh sudah menjalani profesi sebagai kyai yang menikahkan siri.

Berdasarkan pernyataan kyai tersebut dengan mengambil indikator ratarata usia dari pendahulu kyai tersebut adalah 50 tahun dan rata-rata usia kyai mulai menikah adalah 25 tahun dan mempunyai anak maka bisa diperkirakan bahwa fenomena nikah siri di Warurejo sudah ada sejak 175 tahun yang lalu. Sejak etnis Madura yang melakukan pelarian ke Warurejo kemudian melakukan tindakan nikah siri. Pada waktu itu belum ada pencatatan resmi dari negara sehingga pada setiap peristiwa perkawinan yang terjadi pada masyarakat belum tercatat. Ketika pencatatan perkawinan belum disadari secara luas di masyarakat termasuk di Warurejo nikah siri serta kawin kontrak sudah dianggap sebagai nikah resmi. Warga masyarakat melegalisasi setiap pasangan yang telah menikah siri atau pun kawin kontrak sebagai pasangan yang sah.

Pada awalnya nikah siri di Warurejo hanya berlangsung sesama etnis Madura yang melakukan migrasi ke Warurejo, sehingga belum memakai tarif (dikomersilkan). Mereka menikah siri karena didasari oleh kebutuhan biologis. Karena pada masa itu yang melakukan migrasi umumnya adalah kaum laki-laki dan tidak membawa isteri sehingga mereka melakukan nikah siri sesama migran.

Namun lama-kelamaan, nikah siri sudah merupakan hal yang biasa dan lumrah sehingga nikah siri tidak hanya dilakukan oleh para migran tetapi pasangan atau laki-laki yang berasal dari luar Warurejo boleh menikah siri di Warurejo. Seiring dengan berjalannya waktu dan untuk mempertahankan kelangsungan hidup para migran serta adanya pengaruh negatif gaya hidup konsumtif, maka nikah siri mulai dilandasi oleh motif-motif ekonomi.

Nikah siri tidak hanya sebagai alat untuk melegalkan hubungan seks untuk menghindari perzinaan, namun dijadikan sebagai salah satu solusi untuk meningkatkan kehidupan ekonomi, khususnya bagi mereka yang terlibat dalam jaringan nikah siri. Dalam hal ini teori Weber (Ritzer, 2003; Turner, 2001; Ken, 2001) melihat bahwa nikah siri dijadikan instrumen untuk mencapai tujuan, yaitu ekonomi. Para pelaku maupun mafia nikah siri mempunyai harapan-harapan, yaitu jika seorang perempuan menikah siri dengan seorang laki-laki yang cukup kaya menurut penilaian mereka (yang terlihat dari segi materi; mengendarai mobil), maka harapan-harapan itu semakin tinggi untuk dapat meningkatkan ekonomi keluarga.

Fungsi manifes nikah siri bagi 
Nikah Siri di Warurejo ... - Thriwaty Arsal, dkk.

pelaku adalah untuk memenuhi tuntutan masyarakat agar seorang perempuan yang berstatus janda untuk menikah walaupun siri, sementara fungsi latennya adalah ekonomi. Kondisi ini menurut Merton (1949) bahwa fungsi manifes membantu aktor beradaptasi dalam sistem dan dilakukan dengan penuh kesadaran sedangkan fungsi latennya yang berupa ekonomi itu berada di dalam sehingga tidak tampak di permukaan.

Fungsi manifes dari nikah siri tidak hanya berlaku bagi perempuan janda namun juga bagi perempuan yang masih perawan, apabila sudah tiba masanya untuk menikah namun belum melakukan pernikahan. Jadi, pernikahan bagi masyarakat Warurejo adalah untuk memenuhi tuntutan masyarakat agar tidak melanggar norma. Selain itu, nikah siri dijadikan instrumental untuk meningkatkan kehidupan ekonomi keluarga.

Berdasarkan informasi yang peneliti peroleh dari salah satu tokoh masyarakat bahwa desa Warurejo tidak bisa dikategorikan masyarakat miskin dalam hal ekonomi, namun informasi ini berbeda dengan data yang peneliti peroleh dari beberapa pelaku nikah siri yang mengatakan bahwa dengan menikah siri dapat meningkatkan ekonomi dan juga merupakan suatu kebanggaan tersendiri (prestise) karena bisa menikah siri berkali-kali.

Ekonomi yang merupakan fungsi laten menurut Durkheim (Ritzer, 2003 dan 2007; Turner, 1998 dan 2001) bahwa di dalam masyarakat terdapat berbagai macam kebutuhan yang harus dipenuhi yang merupakan refleksi dari fungsifungsi yang terdapat dalam masyarakat. Kebutuhan terhadap ekonomi menyebabkan pelaku terkadang mengabaikan fungsi negatif yang diakibatkan oleh nikah siri, misalnya adanya kekerasan dalam rumah tangga. Jika terjadi perceraian, maka perceraian itu hanya disampaikan melalui broker atau pesan pendek melalui telepon seluler.

Laki-laki yang akan menceraikan isterinya memanfaatkan hand phone untuk memudahkan tindakan perceraian melalui pesan singkat. Sebelum hand phone populer pada masyarakat Warurejo, perjanjian perceraian dilakukan dalam 2 bentuk, yaitu (1) Perjanjian perceraian diucapkan pada saat akad nikah. Kalau suami tidak datang dalam jangka waktu 1 bulan maka otomatis terjadi perceraian; (2) Perjanjian perceraian dalam bentuk surat pernyataan. Jika terjadi perceraian pada pasangan nikah siri maka modin akan membuatkan formulir surat perjanjian. Berdasarkan surat cerai yang di buat oleh modin, maka pasangan nikah siri sudah dianggap bercerai dan bukan lagi sebagai pasangan suami isteri, sehingga perempuan berhak untuk menikah siri dengan laki-laki lain.

Apapun dampak negatif nikah siri mereka akan menerimanya sebagai suatu takdir. Walaupun suatu takdir dan konsekuensi dari pernikahan siri bagi perempuan namun tindakan laki-laki yang menceraikan perempuan melalui pesan pendek ataupun meninggalkan perempuan tanpa alasan yang jelas dan tidak pernah kembali lagi merupakan suatu penindasan dan ketidakadilan yang dialami perempuan. Penindasan terhadap perempuan, menurut Fakih (1999), sudah ada sebelum munculnya kapitalisme di mana laki-laki mengontrol produksi untuk perdagangan, mendominasi hubungan sosial dan politik dan perempuan direduksi menjadi bagian dari property. Sejak itu dominasi laki -laki dimulai, dan sesungguhnya penindasan perempuan itu bersifat struktural.

Apapun konsekuensi negatif yang diakibatkan oleh pernikahan siri, perempuan dan anak yang menjadi korban, bukan masyarakat secara kese- 
luruhan. Keputusan perempuan untuk menikah siri berkali-kali didasari oleh faktor ekonomi. Selain faktor ekonomi, norma sosial dan budaya ikut mendukung perempuan dalam mengambil keputusan untuk menikah siri setelah ditinggal pasangannya.

Di desa Warurejo, bila seorang pria datang dengan berdandan necis dan mengendarai mobil mewah, tanpa mempertimbangkan suku dan etnisnya, apakah Jawa, Madura, Arab, China, Jepang bahkan Korea, duda atau masih berstatus suami, masyarakat tidak mempersoalkan karena banyak yang menginginkannya untuk dijadikan suami siri.

Sejak nikah siri dikomersilkan orang-orang luar dari berbagai profesi, khususnya laki-laki pencari pasangan nikah siri yang disebut oleh para broker sebagai pasien berdatangan ke Warurejo untuk membuktikan informasi yang berkembang bahwa Warurejo adalah desa nikah siri. Laki-laki dari luar yang pencari pasangan di Warurejo disebut sebagai "pasien" oleh para broker, karena laki-laki yang datang dianggap sebagai orang yang membutuhkan obat dan broker siap mengobati sang pasien dengan cara mencarikan obat yang dalam hal ini obatnya adalah perempuan untuk dijadikan isteri simpanan. Nikah siri di Warurejo tidak hanya terkenal di Jawa Timur tetapi juga di Indonesia bahkan ke luar negeri.

\section{Nikah Landasan}

Setelah periode pernikahan yang berlangsung antar migran, maka istilah pernikahan di Warurejo mengalami perubahan dengan istilah khusus untuk nikah siri yakni nikah landasan. Nikah landasan adalah nikah siri yang bermotifkan imbalan dalam bentuk lahan pertanian atau tegalan. Seorang lelaki yang menginginkan kawin kontrak atau nikah siri harus memberikan imbalan semacam mahar, berupa tanah untuk lahan pertanian (sebagai landasan) kepada si perempuan yang dikawininya sebagai modal bagi perempuan untuk meningkatkan kehidupan ekonomi. Dengan lahan pertanian yang ada, maka perempuan bisa menggarap lahan sawahnya sendiri atau memakai buruh tani. Nikah landasan masih dilakukan oleh sebagian masyarakat di Warurejo.

Nikah landasan terutama ditujukan kepada laki-laki Arab yang datang ke Warurejo dengan alasan bahwa kebanyakan laki-laki Arab yang datang adalah berprofesi sebagai pedagang, yang menurut anggapan masyarakat bahwa etnis Arab yang datang pastilah orang yang memiliki banyak uang, maka mereka akan mengajukan mahar dengan diberi landasan, misalnya sawah, ladang atau tegalan. Pada masamasa itu kebanyakan yang datang adalah etnis Arab yang akan menikah dengan perempuan Warurejo. Mereka melakukan pernikahan dengan perempuan Warurejo untuk dimadu (sebagai isteri simpanan) karena perempuan Warurejo dianggap "orangorangnya nrimo" (tidak banyak menuntut) bila suami jarang mengunjungi atau terlambat memberi nafkah.

Awal terjadinya migrasi, nikah siri hanya berlangsung dengan sesama etnis Madura dan pada akhirnya perempuan Warurejo melakukan perkawinan siri dengan etnis Arab. Walaupun memiliki isteri simpanan di Warurejo namun mereka tidak tinggal dan menetap di Warurejo.

Proses perkawinan yang dilakukan oleh etnis Arab diawali ketika seorang laki-laki Arab mengunjungi rumah kyai untuk dicarikan jodoh, kemudian kyai mencari dan mendatangi rumah warga yang mempunyai anak 
Nikah Siri di Warurejo ... - Thriwaty Arsal, dkk.

perempuan yang belum menikah atau janda. Jika kyai sudah menemukan seorang perempuan yang bersedia menikah dengan etnis Arab, maka foto perempuan tersebut akan disampaikan ke laki-laki Arab. Apabila laki-laki Arab tersebut merasa cocok, maka saat itu juga akan diadakan akad nikah oleh kiai, yang menurut masyarakat Warurejo kiai lebih afdol melaksanakan akad nikah daripada orang tua kandung.

Proses nikah siri dilaksanakan di rumah pihak perempuan dan disaksikan oleh dua orang laki-laki, dua orang saksi dihadirkan dan biasanya disiapkan dari pihak perempuan dengan mahar landasan misalnya sawah, ladang atau tegalan. Jika laki-laki Arab tidak menyukai dan menolak perempuan tersebut, maka kyai akan mencari perempuan lain sampai laki-laki Arab merasa cocok, lalu terjadilah proses akad nikah. Setelah menikah laki-laki Arab tidak bisa tinggal dan hidup bersama, hanya sewaktu-waktu datang dan berkunjung ke pasangannya di Warurejo karena etnis Arab yang melakukan nikah siri di Warurejo sudah punya isteri. Umumnya etnis Arab berdomisili di beberapa wilayah kecamatan dan kabupaten di Jawa Timur yang sampai saat ini tetap mempertahankan bahasa Arab.

Faktor utama yang menyebabkan perempuan Warurejo menikah landasan dengan laki-laki Arab adalah: (1) Perempuan merasa bangga bila dinikahi oleh keturunan Nabi Muhammad SAW, yang juga etnis Arab; (2) Bangga bila bisa memiliki "sesuatu yang lebih".

Nikah landasan masih dilakukan oleh sebagian masyarakat di Warurejo, namun, nilai maharnya kini semakin mengecil. Bukan tanah lagi yang diberikan pihak lelaki kepada pihak perempuan yang dinikahi, melainkan mesin jahit atau obras sehingga dikenal dengan istilah nikah mesin jahit. Pada awalnya istilah nikah mesin jahit muncul karena laki-laki yang mau nikah siri tidak memiliki sawah dan hanya mampu membeli mesin jahit. Dengan modal mesin jahit laki-laki bisa nikah siri. Sekarang sudah nengalami perubahan, bukan lagi nikah landasan atau nikah mesin jahit tapi lebih mengarah ke uang, perhiasan emas, alat elektronik atau rumah. Sejak itu dimulailah komersilisasi nikah siri yang memunculkan jaringan nikah siri yaitu broker dan kyai/modin "spesialisasi" nikah siri.

Berdasarkan hasil wawancara dengan salah seorang perangkat Desa Warurejo, informan dan juga pelaku nikah siri Herman (40 tahun) mengatakan bahwa:

Nikah siri versi Warurejo dulu itu yang penting bisa dibelikan mesin jahit maka nikah siri bisa berlangsung tapi sejak masyarakat luar mulai mengetahui bahwa Warurejo adalah tempat untuk nikah siri bagi siapa saja yang akan menikah siri, maka sejak itu nikah siri menjadi mahal, terutama bagi orang luar/laki-laki yang datang untuk menikah maka mereka akan diberi tarif sesuai status perempuan yang akan dinikahi (perawan/janda) termasuk usia, paras wajah (cantik atau biasa-biasa saja). Masyarakat dan perempuan yang akan dinikahi siri mempunyai anggapan bahwa laki-laki yang datang ke Warurejo untuk menikah siri pastilah mempunyai uang yang banyak, oleh karena itu wajar saja kalau perempuan janda/perawan memasang tarif apalagi jika melalui broker tarifnya bisa lebih mahal lagi karena broker juga akan mendapatkan duit dari jasa mencarikan pasangan bagi perempuan terutama yang sudah janda.

Berdasarkan wawancara di atas memperlihatkan bahwa pihak-pihak yang terlibat (broker) dalam pernikahan siri mempunyai kepentingan terselubung (laten) dengan dalih menolong atau membantu mencarikan pasan- 
gan; baik bagi perempuan janda/ perawan maupun bagi pasien dengan imbalan ekonomi. Bagi broker, apa yang mereka lakukan tak ubahnya sebuah bisnis, sama-sama diuntungkan, janda/ perawan mendapatkan seorang suami dan sebaliknya pasien pun dapat melakukan pernikahan dengan perempuan sesuai dengan kriteria yang diinginkan. Sementara itu, broker sebagai perantara memperoleh keuntungan ekonomi yang jauh lebih banyak daripada perempuan itu sendiri.

Sebagai broker mereka memiliki "keahlian" untuk memikat pasien, misalnya, mereka harus pandai “mempromosikan" perempuanperempuan janda/perawan untuk menarik minat pasien agar dijadikan pasangan nikah siri. Semakin banyak yang diminati dan dinikahi oleh pasien, semakin banyak keuntungan ekonomi yang diperoleh broker dan bisnis model ini tidak mempunyai resiko tetapi keuntungannya menjanjikan. Pasangan (pasien) yang sudah menikah tidak akan melakukan tuntutan terhadap broker jika pernikahan mereka gagal atau salah satu pihak telah dikecewakan oleh pasangannya.

\section{Mafia Nikah Siri}

Masyarakat Warurejo tidak bisa memperkirakan sejak kapan komersilisasi nikah siri mulai berlaku di Desa Warurejo, namun yang pasti sejak adanya komersilisasi maka sejak itu pula mulai memunculkan lahan pekerjaan baru bagi para broker dan kyai/ modin. Bagi para broker pekerjaan utama mereka sebelum adanya komersilisasi nikah siri adalah sebagai tukang ojek, namun mengalami perubahan setelah nikah siri dikomersilkan oleh masyarakat. Sehingga tukang ojek tidak lagi menjadi pekerjaan utama tetapi sebagai pekerjaan sampingan. Hal yang sama juga dialami oleh kyai/modin Aziz (60 tahun) yang memanfaatkan situasi tersebut, sebagaimana yang dituturkan oleh kyai sebagai berikut:

Saya tidak tahu dan tidak bisa memastikan sejak kapan nikah siri dikomersilkan, saya hanya tahu bahwa saya adalah generasi ke tujuh dari kakek dan bapak saya yang semuanya berprofesi sebagai modin yang menikahkan pasangan yang ingin menikah siri, karena saya sudah tua maka saya berharap anak saya bisa mengikuti jejak saya karena pekerjaan sebagai modin cukup menjanjikan dari segi ekonomi.

Salah seorang informan Joko (25 tahun) yang merupakan generasi ke empat yang berprofesi sebagai broker mengatakan hal sama dengan kyai bahwa:

Sejak dulu broker itu sudah ada, kakek saya dulunya juga sebagai tukang ojek sekaligus sebagai broker nikah siri, jadi kapan persisnya saya juga tidak tahu, yang pasti broker itu sudah ada sejak dulu dan sudah berlangsung lama dan sebagai broker saya menikmatinya karena bisa mendapatkan keuntungan ekonomi yang lumayan dalam hitungan jam/ hari tergantung kesepakatan.

Masyarakat Warurejo tidak merasa dirugikan dengan kehadiran para broker. Mereka dianggap membantu mencarikan jodoh bahkan menurut beberapa perempuan pelaku nikah siri di Warurejo bahwa mereka justeru berterima kasih pada broker sehingga mereka tidak mempermasalahkan ketika akhirnya mengetahui broker akan memperoleh uang yang lebih banyak dibandingkan perempuan pelaku nikah siri. Bagi mereka, tindakan para broker tersebut merupakan hal biasa karena dengan jasa broker mereka bisa terbantu secara ekonomi dengan mendapatkan pa- 
Nikah Siri di Warurejo ... - Thriwaty Arsal, dkk.

sangan. Broker bersifat dwi fungsi di masyarakat Warurejo: sebagai tukang ojek dan broker nikah siri.

Broker tidak bekerja sendiri tetapi memiliki jaringan yang sangat rapi dan terkoordinir. Broker memiliki peran dan tugas masing-masing yang berbeda yang di koordinir oleh kyai yang disebut juga "kepala jaringan". Mafia/ jaringan nikah siri terdiri dari, pertama, Broker pertama yaitu yang berperan sebagai mediator menghubungkan lakilaki pencari pasangan dengan perempuan (perawan atau janda) yang akan menikah siri. Selain itu, broker sebagai penentu dalam pemasaran jasa seks dengan menyebarkan informasi kepada setiap laki-laki yang datang sendirian ke Warurejo dengan aturan main dan penentuan tarif. Broker yang berprofesi sebagai tukang ojek mengumpulkan informasi, baik dari broker pemasok maupun ketika mengantar penumpang, siapa-siapa saja janda ataupun perawan yang siap untuk dinikahi. Kemudian tukang ojek mengunjungi mereka untuk meminta foto-foto yang akan ditawarkan kepada pasien yang mencari istri siri.

Kedua, Broker kedua berperan sebagai "pemasok" yang berperan mengumpulkan informasi tentang perempuan janda/perawan, baik yang terdapat di desa Warurejo maupun di Desa Manggis dan Desa Rambutan. Proses kerjasama yang dilakukan antara broker dengan pemasok yaitu, pemasok yang memberikan informasi kepada broker (tukang ojek) tentang perempuan janda yang akan menikah siri. Mereka punya "stock" perempuan janda yang siap untuk menikah siri.

Ketiga, Broker yang ketiga, yaitu kepala yang disebut oleh kelompoknya sebagai kyai yang memiliki tanggungjawab untuk menyediakan fasilitas akomodasi penginapan dan makanan sehari -hari serta memainkan peranan penting dalam proses terjadinya nikah siri. Selain itu, kepala bertugas sebagai penghulu yang menikahkan pasangan nikah siri dan membagikan uang dari hasil nikah siri kepada perempuan yang telah dinikahi siri, broker (tukang ojek), pemasok, aparat desa dan polisi sebagai biaya keamanan. Di Desa Warurejo terdapat dua kyai (kepala) yang masingmasing mengkoordinir beberapa broker sebagai penghubung untuk "menjaring" lelaki yang datang mencari pasangan.

Seringkali pelaku nikah siri "dikibuli" oleh broker sekaligus sebagai mafia nikah siri. Bukan rahasia lagi jika para perempuan pelaku nikah siri sering dikibuli oleh para broker, namun mereka tidak berdaya untuk melepaskan diri dari broker karena ada ketergantungan (dependency) di antara mereka. Broker memperoleh keuntungan secara ekonomi sementara perempuan pelaku nikah siri, bisa terbantu tidak hanya secara ekonomi namun yang lebih utama adalah bisa memperoleh jodoh walaupun terkadang tidak sesuai dengan harapan mereka.

Faktor utama mengapa laki-laki luar Warurejo melakukan nikah siri di Warurejo karena terdapat mitos yang berkembang bahwa perempuan Madura masih "ngetan" dan "kesat" walaupun berkali-kali melakukan nikah siri. Mitos yang berkembang bahwa perempuan Warurejo "ngetan" dan "kesat" sudah terkenal pada masyarakat Jawa Timur sehingga banyak laki-laki yang berasal dari luar Warurejo yang ingin mencoba dan membuktikan mitos tersebut.

Hasil wawancara dengan informan, perempuan pelaku nikah siri Yati (24 tahun), yang pernah menikah siri sebanyak 8 kali, menuturkan bahwa: Kebanyakan laki-laki yang datang ke Warurejo untuk mencari isteri biasanya hanya iseng dan coba-coba dan tidak ada yang benar-benar serius, ya sekedar iseng aja untuk dijadikan isteri simpanan walaupun hanya 
beberapa bulan, setelah itu menghilang dan tidak pernah kembali ke Warurejo.

Di Warurejo, kawin-cerai begitu mudah dan merupakan hal yang biasa. Perempuan pelaku nikah siri, menyadari konsekuensi sebagai isteri siri ketika ditinggal pergi dan suaminya tidak pernah kembali, namun mereka menganggap bahwa itu adalah takdir yang harus dijalani. Proses cerai bisa lewat komunikasi telepon seluler, melalui surat atau lisan. Perceraian itu bukan disampaikan langsung oleh sang suami dan tidak sedikit yang melalui broker, yaitu suami menitip pesan cerai kepada sang istri.

Tidak jarang suami mengucapkan cerai kepada istrinya melalui telepon, setelah bercerai perempuan yang berbekal harta pribadinya membawa anaknya pulang ke rumah orangtuanya. Tidak ada pembagian harta bersama (gonogini) yang didapat karena umumnya harta yang dibagikan tidak ada. Kalau pun ada kekayaan bersama dan bekas istri mau menggugat serta menuntut bagiannya, pengadilan agama sulit memproses sebab perkawinan mereka tidak diperkuat akta nikah sebagai alat bukti di pengadilan untuk memeriksa dan memutuskan gugatan perceraian. Anak pun menjadi korban perceraian karena bekas pasangan suami-istri sudah menikah lagi hingga hubungan komunikasi di antara mereka terputus. Inilah salah satu dampak negatif yang diakibatkan oleh nikah siri.

Mereka yang dilahirkan dari orang tua yang hidup bersama tanpa catatan perkawinan, hanya mempunyai hubungan hukum dengan ibunya, dan tidak punya hubungan hukum dengan bapaknya. Tidak ada paksaan bagi masyarakat untuk mencatatkan perkawinan karena jika kita tidak mencatatkan perkawinan bukan berarti kita melakukan suatu kejahatan. Namun, jelas bahwa hal ini memberikan dampak atau konsekuensi hukum tertentu yang khususnya merugikan perempuan dan anak-anak.

Melalui pencatatan pernikahan yang dibuktikan dengan akta nikah, apabila terjadi perselisihan di antara suami isteri, atau salah satu pihak tidak bertanggung jawab, maka yang lain dapat melakukan upaya hukum guna mempertahankan atau memperoleh haknya masing-masing karena dengan akta nikah suami isteri memiliki bukti otentik atas perkawinan yang terjadi antara mereka. Perubahan terhadap sesuatu termasuk institusi perkawinan, dengan dibuatnya undang-undang atau peraturan lainnya, adalah merupakan kebutuhan yang tidak bisa dihindarkan dan bukan sesuatu yang salah menurut hukum Islam.

Berkaitan dengan pernikahan siri, Majelis Ulama Indonesia menganjurkan agar nikah siri itu dicatatkan (itsbat) secara resmi pada instansi berwenang sebagai langkah preventif untuk menolak dampak negatif/mudharat. Hukumnya menjadi haram karena ada kemudharatan di dalamnya, meskipun memenuhi syarat dan rukun nikah karena ada yang menjadi korban. Menurut Ketua Majelis Ulama Indonesia (MUI) K.H Ma'ruf Amin (Kompas, 15 Februari 2010) bahwa pernikahan itu bisa halal, tetapi bisa juga menjadi haram. Pernikahannya sendiri tidak batal, tapi menjadi haram/berdosa karena ada orang yang ditelantarkan sehingga seorang suami/pasangan nikah siri berdosa karena mengorbankan istri atau anak. Sah tapi haram kalau sampai terjadi korban.

Namun, yang terjadi pada masyarakat Warurejo adalah mereka tidak menyebutnya sebagai korban ketika perempuan yang telah dinikahi siri oleh laki-laki kemudian ditinggalkan 
Nikah Siri di Warurejo ... - Thriwaty Arsal, dkk.

begitu saja tanpa ada kabar berita. Mereka justru menganggap sebagai takdir yang harus dijalani. Oleh karena itu, ketika ditinggal oleh pasangannya maka perempuan siap untuk mencari pasangan lagi. Perawan atau perempuan janda merasa bangga dan prestise walaupun menikah secara siri.

Menurut masyarakat Warurejo pencatatan perkawinan dalam bentuk akta nikah tidak membudaya meskipun orangtua yang melakukan pernikahan telah dicatatkan di Kantor Urusan Agama dan berdasarkan Undang-Undang No.1 Tahun 1974 dan memiliki surat nikah. Mereka enggan untuk mengurus akte kelahiran bagi anaknya. Akte kelahiran dianggap kurang penting bagi penduduk Warurejo karena akte kelahiran dan surat-surat berharga lainnya seperti juga surat nikah hanyalah selembar kertas yang tidak menghasilkan uang, justeru dengan mengurus suratsurat berharga tersebut akan menghabiskan uang. Sehingga terdapat asumsi yang berkembang bahwa untuk apa nikah di KUA tapi bukunya tidak dimiliki, lebih baik nikah siri karena sama saja nikah di KUA yang penting sah.

Mereka tidak memahami bahwa perkawinan yang telah melalui pencatatan adanya kemaslahatan umum, artinya kaum wanita terlindungi hak asasinya dan tidak dilecehkan. Menurut hukum positif Indonesia, nikah siri itu tidak diakui sama sekali apalagi anak yang dilahirkan dianggap sebagai anak yang lahir di luar pernikahan.

Adanya ikatan perkawinan diakui secara hukum hanya jika dicatat oleh petugas yang ditunjuk. Jadi, di dalam struktur Kantor Urusan Agama itu ada petugas pencatatan Nikah (PPN) yang kita sebut penghulu atau modin. Penghulu itu yang bertanggung jawab untuk mencatat, bukan menikahkan. Terkadang ada salah tafsir bahwa penghulu itu menikahkan, akan tetapi penghulu juga bisa bertindak menjadi naibul (pengganti) wali ketika wali menyerahkan untuk memimpin kewaliannya. Namun harus ada serah terima dari wali yang sesungguhnya, tidak bisa seorang penghulu mengangkat dirinya menjadi wali. Apalagi pihak lain yang mencoba untuk memposisikan dirinya sebagai penghulu yang tidak memiliki surat keputusan dari KUA sebagai penghulu. Sementara di desa Warurejo seorang kyai bisa bertindak sebagai wali hakim, penghulu sekaligus menikahkan bagi pasangan yang akan menikah siri.

Seyogyanya yang berhak menikahkan adalah wali perempuan (orangtua), namun orangtua dalam hal ini bisa saja menyerahkan perwaliannya kepada wali hakim yang telah ditunjuk. Artinya, siapa saja boleh menikahkan, namun hal ini sering disalah tafsirkan. Apalagi pada masyarakat Warurejo yang sangat paternalistik yang mempunyai anggapan bahwa yang paling afdol untuk menikahkan bagi pasangan yang akan menikah adalah kyai yang memang menjadi panutan masyarakat, dan secara otomatis urusan perwalian akan diserahkan kepada kyai. Pasangan yang sudah dinikahkan oleh kyai kemudian hidup sebagai suami istri tanpa mempunyai kutipan akta nikah.

Nikah siri di Warurejo dilaksanakan tanpa sepengetahuan Pegawai Pencatat Nikah (PPN) karena masyarakat beranggapan bahwa tanpa kehadiran aparat yang berwenang juga sudah sah menurut hukum Islam. Mereka menganggap hal tersebut hanyalah hal yang sifatnya administratif saja. Dikarenakan mereka masih awam, ada perasaan takut untuk berhadapan dengan pejabat nikah dan menganggap mereka lebih baik perkawinannya dilaksanakan di depan pemuka agama. Agama Islam dijadikan dalil untuk melegitimasi keinginan-keinginan tertentu yang sifatnya subjektif. 
Jika agama sudah menganggap sah, berarti tidak ada persoalan dengan hal itu, dan masalah kehadiran Petugas Pencatat Perkawinan menjadi syarat mutlak. Namun pencatatan peraturan perundang-undangan yang ada tidak memasukkan sebagai salah satu syarat keabsahan perkawinan, oleh karena itu tidak tepat jika poin itu yang dipersoalkan dan dijadikan landasan argumen karena akan melahirkan ketidakkonsistenan terhadap asas supremasi agama itu sendiri.

Logika itulah yang kemudian melahirkan femomena nikah siri yang berulang-ulang pada masyarakat Warurejo. Selain itu, secara sosial, perempuan yang menjadi janda lebih mudah disoroti oleh masyarakat. Perempuan janda seharusnya menikah walaupun secara siri dengan pria yang berstatus duda atau pun yang sudah mempunyai isteri daripada hidup menjanda. Asumsi masyarakat Warurejo, perempuan janda lebih rawan terhadap pelanggaran norma dan sistem nilai. Hal ini dikarenakan tuntutan masyarakat dalam memahami keperawanan yang lebih dihormati daripada sudah tidak perawan. Dengan dalih untuk menghindari zina dan dosa, perempuan dituntut untuk segera menikah walaupun secara siri.

Perempuan janda lebih rentan terhadap pelanggaran norma. Berbeda dengan laki-laki yang tidak ada tuntutan harus menikah lagi ketika menjadi duda. Perempuan tidak memiliki posisi tawar menawar (bargaining position) dalam menentukan apakah harus menikah lagi atau tidak.

Menurut Fakih (1995), dalam kondisi ini, keluarga dan lembaga sosial dala m masyakat cenderung memproduksi nilai yang ada terutama dalam mensosialisasikan status gender dengan memberikan atribut yang berbeda antara perempuan dan laki-laki dengan membuat aturan-aturan yang berbeda antara laki-laki dan perempuan. Budaya dan adat secara umum melegitimasi struktur hubungan gender yang timpang. Perempuan dituntut untuk menikah lagi sementara laki-laki tidak boleh menentukan pilihan apakah menikah lagi atau tetap menduda.

Usaha mengubah tatanan nilai semacam ini sama sekali bukan usaha yang mudah karena merupakan realitas historis yang berakar pada sistem kosmologi pada masyarakat. Sistem kosmologi ini menurut Berger dan Luckmann (1979) mempengaruhi orientasi hidup manusia yang disebut sebagai universe of meaning (semesta makna).

Seorang perempuan ditutuntut untuk mematuhi aturan-aturan yang berlaku dalam masyarakat yang merupakan suatu ideologi yang sangat mempengaruhi bentuk-bentuk tindakan yang dikenakan terhadap perempuan. Keberadaan suatu ideologi dapat dilihat pada konsep-konsep yang sangat umum digunakan seperti "perempuan yang lemah", "swarga nunut neraka katut", atau konsep kanca wingking" (Abdullah, 2001). Konsep-konsep ini juga terlihat dalam pernikahan siri di Warurejo. Ketika seorang laki-laki yang menikah dengan seorang perempuan dengan mengajukan syarat agar pernikahan tidak didaftarkan pada Kantor Urusan Agama. Untuk menghindari hal-hal yang tidak diinginkan dari pihak-pihak yang berkeberatan dengan adanya pernikahan ini. Syarat ini diajukan kepada pihak perempuan, kalau syarat ini tidak mendapat persetujuan maka pernikahan siri tidak bisa dilaksanakan dan syarat ini tidak hanya diajukan kepada perempuan yang sudah menjanda namun juga berlaku pada perempuan yang masih perawan.

Bagi orangtua yang mempunyai anak perawan, masalah pencatatan bukanlah hal yang mutlak harus dilakukan ketika anaknya akan 
Nikah Siri di Warurejo ... - Thriwaty Arsal, dkk.

melaksanakan pernikahan, yang berarti lepasnya tanggungjawab secara moril dan materi dari orang tua kepada anaknya serta adanya mahar yang akan dipergunakan untuk melaksanakan pesta hajatan pernikahan. Ketika pernikahan yang tidak tercatat di Kantor Urusan Agama, dan pernikahan tidak bisa dipertahankan lagi, maka pasangan akan melakukan perceraian baik melalui kesepakatan ataupun perceraian sepihak yang umumnya dilakukan oleh pihak laki-laki. Faktor inilah yang merupakan salah satu alasan yang menyebabkan perempuan di Warurejo untuk memutuskan melakukan nikah siri berulang-ulang ketika ditinggal atau diceraikan oleh pasangannya di samping faktor sosial, sistem nilai, norma dan budaya, ekonomi, agama, sumber daya alam, pendidikan, pelaku nikah siri dilindungi oleh warga masyarakat dan peran orang tua dalam mendukung eksisnya nikah siri di Desa Warurejo.

\section{SIMPULAN}

Nikah siri pada awalnya hanya berlangsung sesama etnis yang memiliki nasib yang sama melakukan migrasi ke Warurejo dan belum memakai tarif, tapi lebih didasarkan pada kebutuhan biologis. Karena umumnya yang melakukan migran adalah kaum laki-laki yang tidak membawa isteri dan keluarga sehingga banyak dari mereka yang kemudian melakukan perkawinan sesama migran. Lambat-laun pernikahan siri yang terjadi mulai dianggap hal yang biasa dan lumrah. Namun seiring dengan berjalannya waktu dan pengaruh negatif gaya hidup konsumtif, nikah siri mulai dilandasi motif-motif ekonomi yang mulai mengarah ke monetisasi. Sejak nikah siri dikomersilkan maka orang-orang dari berbagai profe- si, khususnya laki-laki berdatangan ke Warurejo untuk mencari pasangan nikah siri yang oleh para broker disebut sebagai pasien. Kedatangan mereka di Warurejo untuk membuktikan informasi yang berkembang bahwa Warurejo sebagai desa nikah siri.

Monetisasi berkembang demi untuk mendapatkan uang. Walaupun di dorong oleh faktor kemiskinan namun ada faktor luar yang mempengaruhi yaitu ingin kaya dan memiliki sesuatu yang lebih. Setelah periode pernikahan yang berlangsung sesama pelarian etnis Madura kemudian mengalami perubahan dengan istilah khusus untuk kawin siri di Warurejo, yakni nikah landasan. Nikah landasan terutama ditujukan kepada laki-laki Arab yang datang ke Warurejo dengan alasan bahwa kebanyakan laki-laki Arab yang datang adalah berprofesi sebagai pedagang, yang menurut anggapan masyarakat pastilah orang yang memiliki banyak uang. Dengan demikian, mereka akan mengajukan mahar dengan diberi landasan, misalnya sawah, ladang atau tegalan. Namun sekarang bukan tanah lagi yang diberikan pihak lelaki kepada pihak perempuan yang dinikahi, melainkan mesin jahit atau obras sehingga dikenal dengan istilah nikah mesin jahit. Pada awalnya istilah nikah mesin jahit muncul karena laki-laki yang mau menikah siri tidak memiliki sawah dan hanya mampu membeli mesin jahit. Dengan modal mesin jahit, maka laki-laki bisa menikah siri di Desa Warurejo.

\section{DAFTAR PUSTAKA}

Abdullah, Irwan. 2001. Seks, Gender dan Reproduksi Kekuasaan. Yogyakarta: Tarawang Press.

Fakih, M. 1999. Analisis Gender dan Transformasi Sosial. Yogyakarta : Pustaka Pelajar Offset. 
Paramita Vol. 25, No. 2 tahun 2015

Merton, K. Robert. 1949. Social Theory and Social Structure. Revised and Enlarged Edition. The Free Press of Glencoe.

- - - - . 1979. The Sociology of Science: Theoretical and Empirical Investigations. University of Chicago Press.

Merton, K.Robert, Carlo Mongardini, Simonetta Tabboni. 1998. Robert K Merton and Contemporary Sociology. Transaction Publisher.

Ritzer, George. 2003. Sosiologi Ilmu Pengetahuan Berparadigma Ganda (Penyadur: Alimandan) Rajawali
Press.

Ritzer, George dan Douglas J Goodman, 2007. Teori Sosiologi Modern (Terjemahan: Alimandan), Jakarta: Kencana.

Turner, Jonathan H (eds). 1998. The Structure of Sociological Theory. Sixth Edition. United States of America: Wadsworth Publishing Company.

Turner, Jonathan H. 2001. Handbook of Sociological Theory. Kluwer Academic Plenum Publisher. New York.

Undang-Undang Nomor 23 Tahun 2006 Tentang Administrasi Kependudukan. Departemen Dalam Negeri Republik Indonesia 2006. 